NOTE

\title{
Polymerization of Symmetrical Dialkylacetylenes (3-Hexyne, 4-Octyne, and 5-Decyne) by $\mathrm{WCl}_{6} \cdot \mathbf{P h}_{4} \mathrm{Sn}$ and $\mathrm{MoCl}_{5} \cdot \mathrm{Ph}_{4} \mathrm{Sn}$
}

\author{
Toshio Masuda, Yoshinori KuWAne, \\ and Toshinobu HIGASHIMURA \\ Department of Polymer Chemistry, Kyoto University, \\ Yoshida, Sakyo-ku, Kyoto 606, Japan.
}

(Received October 6, 1980)

\begin{abstract}
KEY WORDS Coordination Polymerization / 3-Hexyne / 4-Octyne / 5Decyne / Tungsten Hexachloride / Molybdenum Pentachloride / Tetraphenyltin / Polyene /
\end{abstract}

Fairly many studies have appeared on the polymerization of acetylene and monosubstituted acetylenes, and several transition-metal catalysts are now known to provide high polymers. ${ }^{1}$ The polymerization of disubstituted acetylenes, however, remains appreciably difficult, and virtually restricted to the following cases: hexafluoro-2-butyne (anionic catalyst; insoluble polymer), ${ }^{2}$ dicyanoacetylene (anionic catalysts; polymer molecular weight, MW 500), ${ }^{3}$ 1-phenylpropyne $\left(\mathrm{WCl}_{6} \cdot \mathrm{Ph}_{4} \mathrm{Sn}\right.$; polymer MW 6000), ${ }^{4}$ diphenylacetylene (anionic catalysts; polymer $\mathrm{MW} \leqq 1800)^{5}\left(\mathrm{WCl}_{6} \cdot \mathrm{Ph}_{4} \mathrm{Sn}\right.$; insoluble polymer), ${ }^{6} \quad$ 1-chloro-2-phenylacetylene $\left(\mathrm{Mo}(\mathrm{CO})_{6}-h v\right.$; polymer MW $\left.4 \times 10^{5}\right){ }^{7}$ and dialkylacetylenes $^{8-10}$ (vide infra).

Mauret et al. obtained a mixture of linear polymer and cyclic trimer in the reaction of 3hexyne catalyzed by diarylcobalts. ${ }^{8,9}$ The polymer was insoluble in organic solvents and susceptible to air oxidation. Very recently, Katz and Lee obtained mostly insoluble polymers in the polymerization of 2-butyne, 4-octyne, and cyclooctyne by tungstencarbene complexes. ${ }^{10}$

We have reported that $\mathrm{WCl}_{6}$ - and $\mathrm{MoCl}_{5}$-based catalysts are very effective for the polymerization of aromatic acetylenes including disubstituted acetylenes. ${ }^{4,6,7,11}$ Now it seems appropriate to study whether these catalysts can polymerize aliphatic disubstituted acetylenes as well. This paper deals with the polymerization of symmetrical dialkyl- acetylenes (3-hexyne, 4-octyne, and 5-decyne) by use of $\mathrm{WCl}_{6}$ - and $\mathrm{MoCl}_{5}$-based catalysts and with the characterization of polymers formed.

\section{EXPERIMENTAL}

Dialkylacetylenes (3-hexyne, 4-octyne, and 5decyne; Tokyo Chemical Industry Co.) were used without further purification (purities $>99 \%$ ). Unless otherwise stated, polymerizations were carried out at $30^{\circ} \mathrm{C}$ in toluene for $24 \mathrm{~h}$ under a dry nitrogen atmosphere; $[\mathrm{M}]_{0}=1.0 \mathrm{~mol} \mathrm{dm}{ }^{-3}$, [Cat $]=30 \mathrm{mmol}$ $\mathrm{dm}^{-3}$. The 1:1 mixtures of tetraphenyltin and either $\mathrm{WCl}_{6}$ or $\mathrm{MoCl}_{5}$ in solution were aged at $30^{\circ} \mathrm{C}$ for $15 \mathrm{~min}$ before use as catalysts. ${ }^{12}$ Monomer consumptions and polymer yields were determined by gas chromatography and gravimetry, respectively.

\section{RESULTS AND DISCUSSION}

\section{Polymerization of Dialkylacetylenes}

The $\mathrm{WCl}_{6} \cdot \mathrm{Ph}_{4} \mathrm{Sn}$ catalyst is known to effect the polymerization of phenylacetylene, ${ }^{12}$ 1-phenylpropyne, ${ }^{4}$ and cyclopentene. ${ }^{13}$ This catalyst polymerized 3-hexyne to afford a methanol-insoluble polymer in high yield in toluene solution within several hours (Table I). The polymerization proceeded almost quantitatively in halogenated hydrocarbons. Thus, $\mathrm{WCl}_{6} \cdot \mathrm{Ph}_{4} \mathrm{Sn}$ is much more 
Table I. Polymerization of 3-hexyne

\begin{tabular}{rllc}
\hline No. & \multicolumn{1}{c}{ Catalyst } & \multicolumn{1}{c}{ Solvent } & $\begin{array}{c}\text { Polymer } \\
\text { yield } / \%\end{array}$ \\
\hline 1 & $\mathrm{WCl}_{6} \cdot \mathrm{Ph}_{4} \mathrm{Sn}$ & Toluene & 87 \\
$2^{\mathrm{c}}$ & $\mathrm{WCl}_{6} \cdot \mathrm{Ph}_{4} \mathrm{Sn}$ & Toluene & 71 \\
3 & $\mathrm{WCl}_{6} \cdot \mathrm{Ph}_{4} \mathrm{Sn}$ & $\mathrm{CCl}_{4}$ & 95 \\
4 & $\mathrm{WCl}_{6} \cdot \mathrm{Ph}_{4} \mathrm{Sn}$ & $\left(\mathrm{CH}_{2} \mathrm{Cl}\right)_{2}$ & 96 \\
5 & $\mathrm{MoCl}_{5} \cdot \mathrm{Ph}_{4} \mathrm{Sn}$ & Toluene & 16 \\
6 & $\mathrm{WCl}_{6}$ & Toluene & 0 \\
7 & $\mathrm{MoCl}_{5}$ & Toluene & 3 \\
8 & $\mathrm{WCl}_{6} \cdot(1 / 2) \mathrm{CH}_{3} \mathrm{OH}$ & Toluene & 0 \\
9 & $\mathrm{MoCl}_{5} \cdot(1 / 2) \mathrm{CH}_{3} \mathrm{OH}$ & Toluene & 8 \\
10 & ${\mathrm{Fe}(\mathrm{acac})_{3} \cdot 3 \mathrm{Et}}_{3} \mathrm{Al}$ & Toluene & $\sim 0$ \\
11 & ${\mathrm{Ti}\left(\mathrm{O} n-\mathrm{Bu}_{4} \cdot 4 \mathrm{Et}_{3} \mathrm{Al}\right.}_{12}$ & Toluene & $\sim 0$ \\
12 & $\mathrm{TiCl}_{4} \cdot 3 \mathrm{Et}_{3} \mathrm{Al}$ & Toluene & $\sim 0$ \\
\hline
\end{tabular}

a Polymerized at $30^{\circ} \mathrm{C}$ for $24 \mathrm{~h}:[\mathrm{M}]_{0}=1.0 \mathrm{~mol} \mathrm{dm}^{-3}$, $[$ Cat $]=30 \mathrm{mmol} \mathrm{dm}^{-3}$.

b Methanol-insoluble polymer.

c Polymerized for $1 \mathrm{~h}$.

active than any other catalysts ever used for the polymerization of dialkylacetylenes. ${ }^{8-10}$ The $\mathrm{MoCl}_{5} \cdot \mathrm{Ph}_{4} \mathrm{Sn}$ catalyst was less active, but it also gave a methanol-insoluble polymer.

The polymerization of 3-hexyne by $\mathrm{WCl}_{6} \cdot \mathrm{Ph}_{4} \mathrm{Sn}$ and $\mathrm{MoCl}_{5} \cdot \mathrm{Ph}_{4} \mathrm{Sn}$ produced small amounts of methanol-soluble oligomer $(2-10 \%$ of the whole products) in addition to the methanol-insoluble polymer. Hexaethylbenzene (cyclic trimer) was not found in the oligomeric product.

On the other hand, $\mathrm{WCl}_{6}$ and $\mathrm{MoCl}_{5}$ were, by themselves, practically inactive for the polymerization of 3-hexyne (see Table I). Certain oxygen-containing compounds, such as water and methanol, serve as cocatalysts for the $\mathrm{WCl}_{6}$ - and $\mathrm{MoCl}_{5}$-catalyzed polymerization of phenylacetylene. ${ }^{11}$ Methanol, however, was hardly effective as a cocatalyst in the present polymerization.

Ziegler-type catalysts are known to bring about the polymerization of acetylenes: for example, iron (III) chelates- $3 \mathrm{Et}_{3} \mathrm{Al}$ for 1 -alkynes ${ }^{14}$ and phenylacetylene, ${ }^{15} \mathrm{Ti}(\mathrm{O} n-\mathrm{Bu})_{4} \cdot 4 \mathrm{Et}_{3} \mathrm{Al}$ for acetylene, ${ }^{16}$ and $\mathrm{TiCl}_{4} \cdot 3 \mathrm{Et}_{3} \mathrm{Al}$ for phenylacetylene (cyclotrimerization). ${ }^{17}$ For the sake of comparison, the polymerization of 3-hexyne was carried out using these catalysts. Almost no methanol-insoluble polymer, however, was formed. Consequently it is concluded that Ziegler-type catalysts, which are usually heterogeneous, are unsuitable for the polymerization of
Table II. Polymerization of 4-octyne and 5-decyne ${ }^{\mathrm{a}}$

\begin{tabular}{cllc}
\hline No. & Monomer Catalyst & Solvent & $\begin{array}{c}\text { Polymer } \\
\text { yield } / \%\end{array}$ \\
\hline 1 & 4-Octyne $\mathrm{WCl}_{6} \cdot \mathrm{Ph}_{4} \mathrm{Sn}$ & Toluene & 70 \\
2 & 4-Octyne $\mathrm{MoCl}_{5} \cdot \mathrm{Ph}_{4} \mathrm{Sn}$ & Toluene & 13 \\
3 & 5-Decyne $\mathrm{WCl}_{6} \cdot \mathrm{Ph}_{4} \mathrm{Sn}$ & Toluene & 61 \\
4 & 5-Decyne $\mathrm{WCl}_{6} \cdot \mathrm{Ph}_{4} \mathrm{Sn}$ & $\mathrm{CCl}_{4}$ & 57 \\
5 & 5-Decyne $\mathrm{WCl}_{6} \cdot \mathrm{Ph}_{4} \mathrm{Sn}$ & $\left(\mathrm{CH}_{2} \mathrm{Cl}\right)_{2}$ & 65 \\
6 & 5-Decyne $\mathrm{MoCl}_{5} \cdot \mathrm{Ph}_{4} \mathrm{Sn}$ & Toluene & 10 \\
\hline
\end{tabular}

a Polymerized at $30^{\circ} \mathrm{C}$ for $24 \mathrm{~h}:[\mathrm{M}]_{0}=1.0 \mathrm{~mol} \mathrm{dm}^{-3}$, $[$ Cat $]=30 \mathrm{mmol} \mathrm{dm}^{-3}$.

b Methanol-insoluble polymer.

sterically-hindered acetylenes like dialkylacetylenes.

The results for the polymerizations of 4-octyne and 5-decyne are shown in Table II. 4-Octyne and 5decyne were also polymerized in fairly high yields by $\mathrm{WCl}_{6} \cdot \mathrm{Ph}_{4} \mathrm{Sn}$. As the alkyl group became longer, the polymer yield decreased (3-hexyne $>4$-octyne $>5$ decyne). The solvent effects on the polymerization of 5-decyne were similar to those for 3-hexyne. The chlorides of $\mathrm{W}$ and Mo by themselves and the Ziegler-type catalysts described above did not polymerize 5-decyne.

\section{Properties and Structure of Polymers}

The elemental compositions of polymers agreed well with the theoretical values: e.g., Poly(3-hexyne) (Table I, No. 1) Calcd for $\left(\mathrm{C}_{6} \mathrm{H}_{10}\right)_{n}: \mathrm{C}, 87.73 \% ; \mathrm{H}$, $12.27 \%$. Found: C, $87.56 \%$; H, $12.12 \%$. Poly(4octyne) (Table II, No. 1) Calcd for $\left(\mathrm{C}_{8} \mathrm{H}_{14}\right)_{n}$ : C, $87.19 \%$; H, $12.81 \%$, Found: c, $87.18 \% ; \mathrm{H}, 12.83 \%$. Poly(5-decyne) (Table II, No. 3) Calcd for $\left(\mathrm{C}_{10} \mathrm{H}_{18}\right)_{n}: \mathrm{C}, 86.88 \% ; \mathrm{H}, 13.12 \%$. Found $\mathrm{C}$, $86.29 \% ; \mathrm{H}, 13.20 \%$.

The poly(dialkylacetylene)s obtained had the form of white powder. No softening point was observed below $300^{\circ} \mathrm{C}$. In the differential thermal analysis, the polymers showed no endo- or exothermic peak below $200^{\circ} \mathrm{C}$ but complex exothermic peaks above $200^{\circ} \mathrm{C}$. Even though the polymers were exposed to the air at room temperature for a month, no change occurred in the polymer color, elemental compositions or IR spectra. this indicates that the polymers are fairly stable against air oxidation.

The major portions of the polymers $(70-90 \%)$ were insoluble (polymers were precipitated during 
polymerization regardless of the reaction time), and even the soluble fractions became gradually insoluble after isolation. This seems due to crosslinking which occurs slightly and gradually.

The IR spectrum of poly(3-hexyne) showed the following absorptions: $2950-2850$ (s), 1660-1580 (w), $1460(\mathrm{~m}), 1370(\mathrm{~m}), 1310(\mathrm{~m}), 1260(\mathrm{~m}), 1150-$ $1000(\mathrm{~m})$, and $800(\mathrm{~m}) \mathrm{cm}^{-1}$. The weak and broad absorption at $1660-1580 \mathrm{~cm}^{-1}$ is due to the $\mathrm{C}=\mathrm{C}$ stretching of conjugated double bonds along the main chain. The spectra of poly(4-octyne) and poly(5-decyne) were also similar, though a little more complex. The intensities of absorptions at $1150-1000 \mathrm{~cm}^{-1}$ depended on the kind of catalysts used, $\left(\mathrm{WCl}_{6} \cdot \mathrm{Ph}_{4} \mathrm{Sn}\right.$ and $\left.\mathrm{MoCl}_{5} \cdot \mathrm{Ph}_{4} \mathrm{Sn}\right)$, suggesting a difference in the geometric structure of polymers.

${ }^{1} \mathrm{H}$ nuclear magnetic resonance (NMR) and ultraviolet (UV)-visible spectra were measured using the soluble part of poly(5-decyne) which was more soluble than poly(3-hexyne) and poly(4octyne): ${ }^{1} \mathrm{H}$ NMR $\left(\mathrm{CCl}_{4}\right) \delta 2.5-0.5 \mathrm{ppm}$ (broad singlet); $\mathrm{UV}_{\max }$ (cyclohexane) $273 \mathrm{~nm}$ ( $\varepsilon 450$ ). If the present polymerization is accompanied by isomerization to terminal acetylenes, the polymers formed should be colored and show olefinic-proton peaks around $\delta 5-6 \mathrm{ppm}$ in the ${ }^{1} \mathrm{H}$ NMR spectra. Thus the expected polymer structure, $(\mathrm{CR}=\mathrm{CR})_{n}$ $(\mathrm{R}=\mathrm{Et}, n-\mathrm{Pr}, n-\mathrm{Bu})$ is supported.

\section{CONCLUSIONS}

The $\mathrm{WCl}_{6} \cdot \mathrm{Ph}_{4} \mathrm{Sn}$ and $\mathrm{MoCl}_{5} \cdot \mathrm{Ph}_{4} \mathrm{Sn}$ catalysts effectively polymerized 3-hexyne, 4-octyne, and 5decyne. The polymers produced were in the form of white powder, mostly insoluble and sufficiently stable. The polymer structure, $(\mathrm{CR}=\mathrm{CR})_{n}(\mathrm{R}=\mathrm{Et}$,
$n$-Pr, $n$-Bu) was confirmed by IR and ${ }^{1} \mathrm{H}$ NMR spectra.

\section{REFERENCES}

1. See, for a review, M. G. Chauser, Yu. M. Rodionov, V. M. Misin, and M. I. Cherkashin, Usp. Khim., 45, 695 (1976); Russ. Chem. Rev., 45, 348 (1976).

2. e.g., J. A. Jackson, J. Polym. Sci., Polym. Chem. Ed., 10, 2935 (1972).

3. e. g., M. Benes, J. Peska, and O. Wichterle, J. Polym Sci., C, No. 4, 1377 (1963).

4. N. Sasaki, T. Masuda, and T. Higashimura, Macromolecules, 9, 664 (1976).

5. V. M. Misin, P. P. Kisilitsa, N. I. Bolondaeva, and M. I. Cherkashin, Vysokomol. Soedin., Ser. A, 18, 1726 (1976).

6. T. Masuda, H. Kawai, T. Ohtori, and T. Higashimura, Polym. J., 11, 813 (1979).

7. T. Masuda, Y. Kuwane, K. Yamamoto, and T. Higashimura, Polym. Bull., 2, 823 (1980).

8. P. Mauret and G. Guerch, C. R. Acad. Sci., Ser. C, 274, 1340 (1972).

9. P. Mauret, J. Magne, and G. Guerch, C. R. Acad. Sci., Ser. C, 275, 415 (1972).

10. T. J. Katz and S. J. Lee, J. Am. Chem. Soc., 102, 422 (1980).

11. T. Masuda, K. Hasegawa, and T. Higashimura, Macromolecules, 7, 728 (1974), and subsequent papers.

12. T. Masuda, K.-Q. Thieu, N. Sasaki, and T. Higashimura, Macromolecules, 9, 661 (1976).

13. P. R. Hein, J. Polym. Sci., Polym. Chem. Ed., 11, 163 (1973).

14. F. Ciardelli, S. Lanzillo, and O. Pieroni, Macromolecules, 7, 174 (1974).

15. R. J. Kern, J. Polym. Sci., A-1, 7, 621 (1969).

16. H. Shirakawa and S. Ikeda, Polym. J., 2, 231 (1971).

17. A. Furlani Donda, E. Cervone, and M. A. Biancifiori, Recl. Trav. Chim. Pays-Bas, 81, 585 (1962). 